\title{
Geology in the U.S.A: From Passive to Dynamic Earth in 50 years
}

\section{by John C. Maxwell}

Half a century ago there was little opposition in the U.S.A. to the concept of a largely passive Earth characterized by permanent continents and oceans, and affected primarily by slow and reversible vertical movements. Today this has been replaced by a dynamic Earth with great plates in horizontal motion, related to creation of new crust at ocean ridges and destruction of old crust at subduction zones. This article reviews some of the significant observations and ideas that brought about this change.

\section{The Passive Earth Model}

Prior to the 1940s, little was known about the geology and topography of the oceans, other than such gross features as the mid-Atlantic Ridge. Most American geologists assumed that the continents and oceans had persisted in their present locations since early in the Earth's history. Abundant evidence existed for large and small vertical movements of land masses, and duplication of strata in orogenic belts pointed also to lateral movements due to crustal shortening up to several hundred kilometres. Lateral movements of thousands of kilometres within Cenozoic time, now evident for some lithospheric plates, was not conceivable to most American geologists half a century ago.

The close association of an abnormally thick sedimentary sequence with the folded Appalachian Mountains led, in the mid-1800s, to a geosynclinal theory of mountain building. In its various forms, this held that a subsiding trough or "geosyncline," with its thick filling of sediments, localized compressive forces responsible for the observed folding and thrusting. The rise in temperature with deep burial caused metamorphism of sediments and emplacement of plutonic rocks. Geosynclines and their contained sediments were subjected to intense study, culminating in a major synthesis by Marshal Kay (1951). Thereafter, emphasis shifted to other controls on sedimentation and causes of mountain building, but the geosynclinal model was widely accepted in the U.S.A. until the early 1960s.

Although the continent-ocean boundaries were presumably fixed throughout geological time, sediments in the Appalachians and other marginal mountain systems had clearly originated from highlands in areas now occupied by oceans. To resolve this paradox, Charles Schuchert (1931) and others proposed that land masses existed of fshore prior to Appalachian orogeny to provide the sediments (Fig. 1), subsiding after erosion to form a part of the ocean floor. Figure 2, after P.B. King (1959), shows schematically the inferred history of the Appalachian system, from geosyncline to deformed belt.

The cause or causes of crustal shortening expressed in folded and thrust-faulted mountains were subjects of intense interest and debate. The long-held belief that a once molten Earth was cooling and contracting, thus providing for crustal compression, persisted into the $1930 \mathrm{~s}$ and $1940 \mathrm{~s}$. Vertical movements producing domes and horsts were recognized as mechanisms for producing localized mountain masses, but most U.S. geologists rejected vertical tectonics and gravitational displacement as adequate causes for observed crustal shortening.

As early as 1910, the American geologist F.B. Taylor suggested that the youthful mountains bordering western North and South America were caused by westward drifting of these continents away from the poles and toward equatorial zones. At the same time, South America and Africa parted from the mid-Atlantic Ridge, and Asia flowed outwardly into the bordering ocean producing the fringing island ares. Taylor's ideas were compatible with Alfred Wegener's classic studies supporting continental drift.

The drift hypothesis offered an alternative explanation for vanished land masses, such as Appalachia, and for the compression required to produce mountain systems at the continent borders. However, most American geologists rejected the drift concept because the suggested mechanism, involving slow creep of continents over oceanic crust

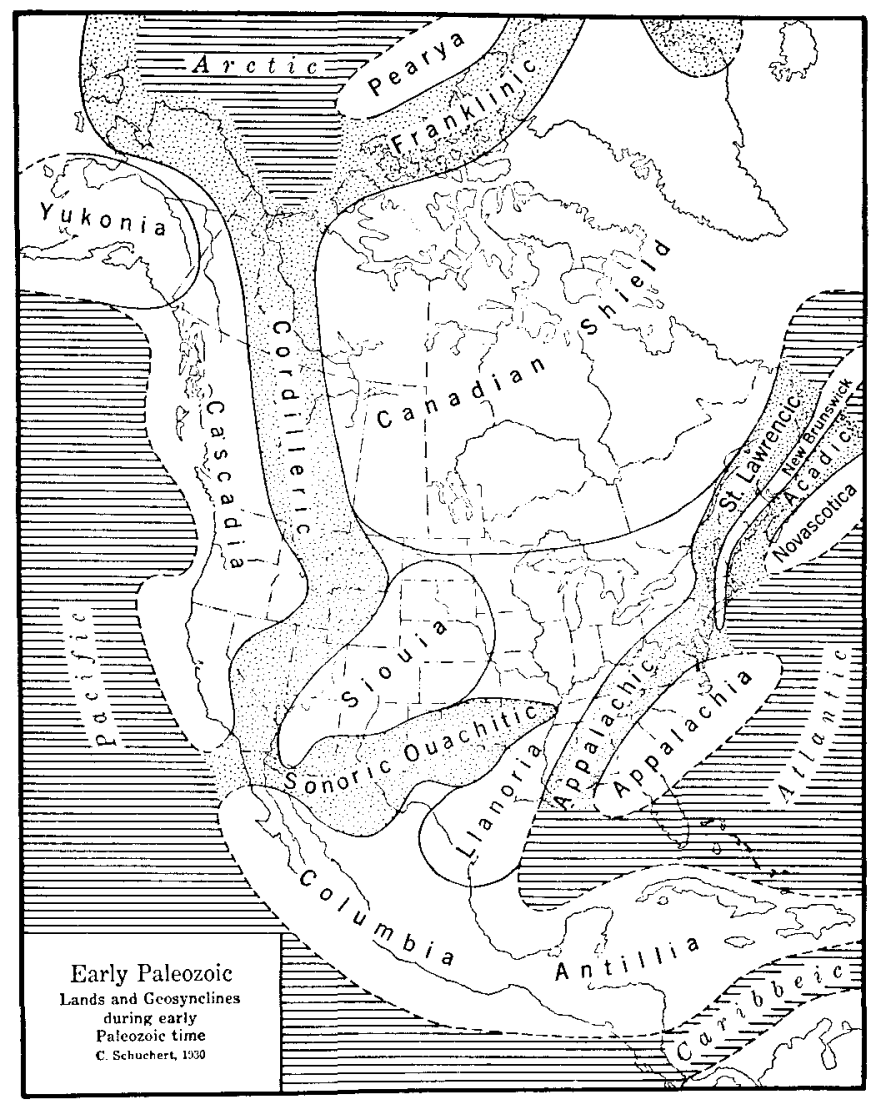

Figure 1: Border lands and geosynclines of North America. From Schuchert, 1931. 


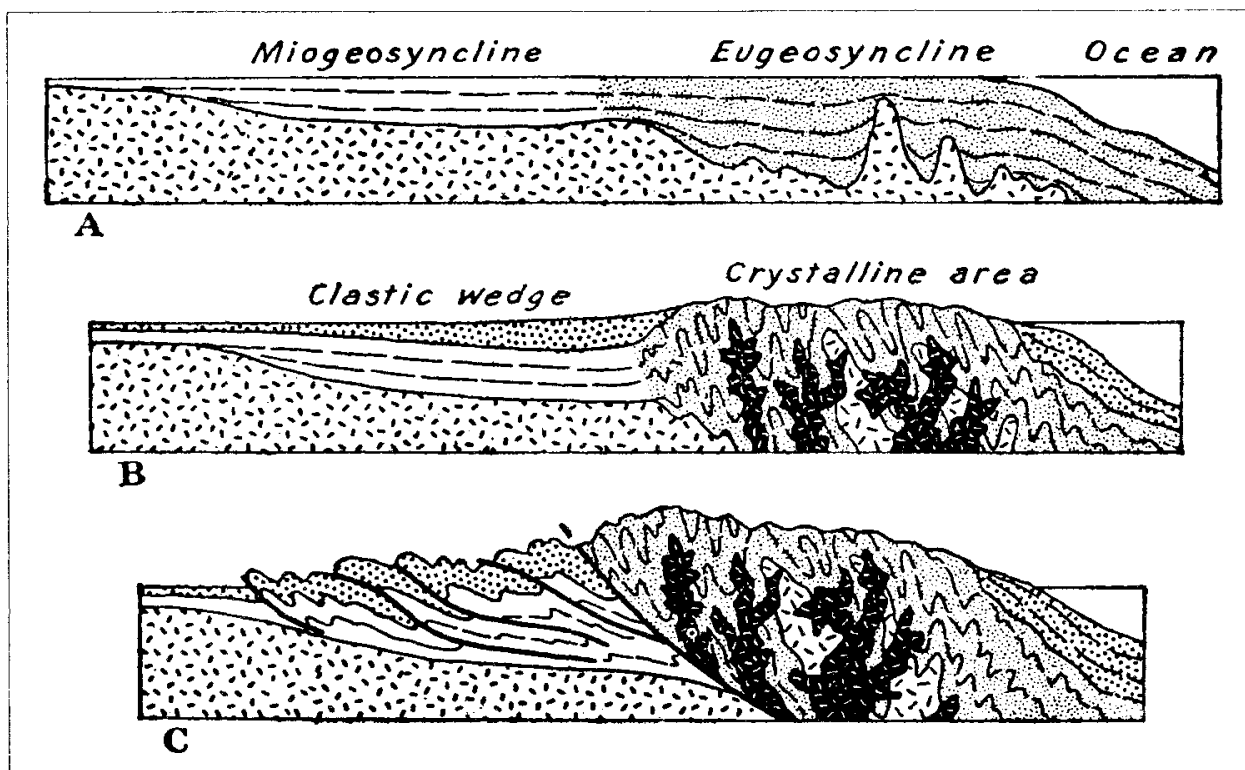

Figure 2: Inferred development of the Appalachian Mountains, from geosyncline to deformed belt. From King, 1959.

under the influence of gravitational forces, was regarded as physically impossible. Evidence in favor of drift thus had to be accounted for in other ways, i.e., disappearing continents to provide sediments, and ephemeral land bridges to explain migrations between similar faunas now separated by great expanse of ocean.

\section{Transition to an Active Earth Model}

Publications of a half century ago laid the groundwork for the current widespread acceptance of a dynamic earth model. In 1928 N.L. Bowen provided the foundation for

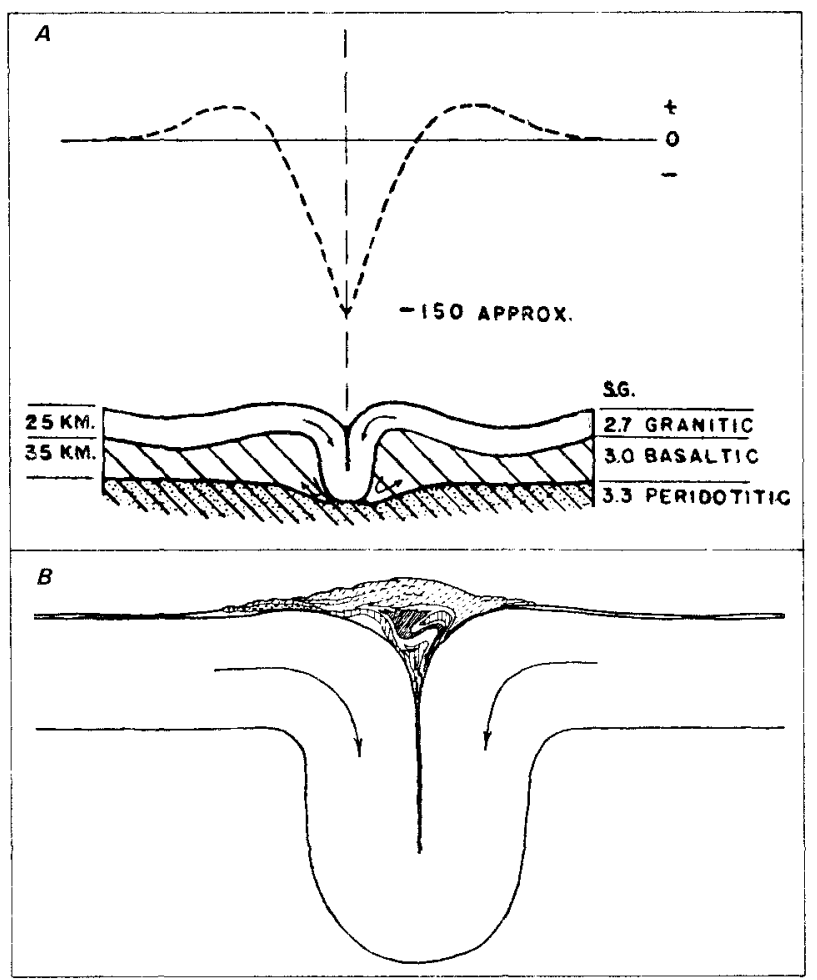

Figure 3: (A) Formation of a "tectogene"; (B) the Alps superimposed on a "tectogene." From Hess, 1939. the East Indies trench and arc, discovering the large, paireo negative and positive gravity anomalies associated respec tively with the trench and volcanic arc. He calculated tha: the gravity anomalies reflected a huge downfold of the lithosphere and an accompanying up-arching of the volcanic arc.

A colleague of Vening Meinesz, Phillip Kuenen (1934) constructed a scale model of such a downfold, and suggester that sediments deposited in its developing surface trougt would be deformed, creating folded and thrust-faultec mountains. He called this system a "tectogene." H.H. Hes (1939), who had accompanied Vening Meinesz on a gravit: measuring cruise in the West Indies and had also studie ultramic rocks, showed that belts of these rocks are char acteristic of both modern island arcs and ancient mountai systems. He proposed that the mountains were generated it tectogenes during crustal compression and shortening (Fig 3). In his 1939 paper, Hess concluded: "Thus there is prob ably some relation between basins of sedimentation an deformations, but it may not be the direct cause and effee relationship which is usually postulated."

In calculating the magnitude of forces available for moun tain-building, David Griggs (1939) concluded that convectio: was the most likely driving force, and constructed dimen sionally correct scale models. Somewhat later, Hug Benioff (1955) described the zones of earthquakes tha extend to depths of as much as $700 \mathrm{~km}$ beneath island arc and mountains bordering the Pacific Ocean (Fig. 4). Thes now well-known "Benioff zones" are incompatible with th tectogene hypothesis but favor the plate subduction mode: introduced later.

The $1950 \mathrm{~s}$ and $1960 \mathrm{~s}$ witnessed explosive growth of geo physical and geological exploration of the oceans. Bathy metric and refraction seismic surveys revealed major topo graphic features on and the regional structure of the oceas. crust. Interpretative bathymetric charts of the Nort ; Atlantic Ocean compiled by Heezen, Tharp and Ewing i 1959 and Heezen and Tharp in 1968 demonstrate th remarkable increase in knowledge in one decade.

Building on the concept of mantle convection, R.S. Diet: (1961) and Hess (1962) independently suggested sea-floo: spreading. Meanwhile, magnetic surveys from offshor California revealed linear, northward-trending magneti: anomalies, offset across great eastward-trending fractur zones (Mason and Raff, 1961). These puzzling features wer soon explained, largely as a result of research that estab lished the existence of periodic reversals of the earth' magnetic field (Cox, Doell and valrymple, 1963). In 
survey of the Carlsberg Ridge, Vine and Matthews (1963 demonstrated that magnetic anomaly stripes were symmetrically disposed on either side of the ridge. They showed also that the symmetrical pattern could not be explained by local topography and suggested that it recorded the rise of newly created oceanic crust, which was magnetized in the earth's field as it cooled through the Curie temperature and then spread laterally from the ridge.

\section{The Advent of Plate Tectonics}

In the next eight years the bare bones of the plate tectonics hypothesis were fleshed out. A "hot-spot" origin for the islands of the Hawaiian chain was suggested in 1963 by J. Tuzo Wilson, who later introduced the concept of transform faults and outlined the basic kinematics of sea-floor spreading and continental drift (1965). L. Sykes (1967) demonstrated by earthquake data that the sense of motion across a transform fault on the mid-Atlantic Ridge was that predicted by Wilson, and incompatible with a strike-slip interpretation. Work by Isacks, Oliver and Sykes (1968)

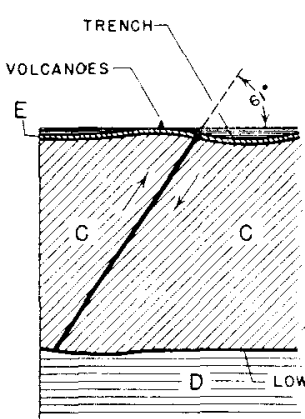

OGEANIO

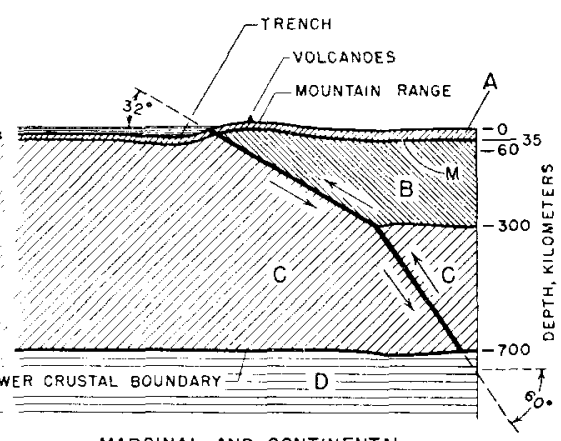

MARGINAL AND CONTINENTAL note exaggeration of surface rebief.

Figure 4: Geometry of deep faults based on earthquake zones ("Benioff zones") associated with Pacific Island arcs. From Benioff, 1955.

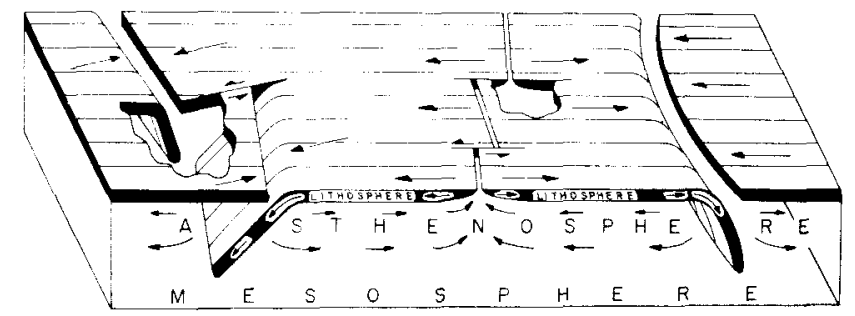

Figure 5: Origin and consumption of ocean crust, based on earthquake seismic data. From Isacks, oliver and Sykes, 1968.

provided the seismic basis for the plate tectonics model accepted for ocean crust at regions of spreading and subduction (Fig. 5). The same year, James lleirtzler and colleagues at Woods Hole Oceanographic Institution summarized existing data on magnetic anomalies and on directions and rates of sea-floor spreading, generating a time scale based on geomagnetic reversals.

The enormously productive ocean-drilling program, begun during this period and continuing today, proved early in its operations that the magnetic stripes reflect global magnetic reversals and that the geomagnetic time scale is both valid and useful in ocean exploration and geological mapping (A. Naxwell, 1970). A seminal study by Hatherton and Dickinson (1969) related variations in chemical composition of andesitic volcanics to the depth of the Benioff zone. $\mathrm{T}$.
Atwater (1970) analyzed the progressive interaction of oceanic and continental crust as different sectors of the East Pacific spreading ridge reached and were subducted beneath the North American continental crust, and as the Pacific-North American plate boundary evolved from a trench to a transform fault. The same year an influential study of mountain belts and the new global tectonics was published by Dewey and Bird. Their diagrammatic cross sections (Fig. 6) proved enormously durable, being replicated with minor changes in hundreds of papers since then.

Jason Morgan in 1968 showed that the movement of plates relative to each other can be easily calculated using poles of rotation. Three years later he introduced the concept of plumes in connection with mantle convection (Morgan, 1971). These plumes rise from the lower mantle and impinge on the base of the lithosphere, producing the "hot-spot traces" (chains of volcanic islands and seamounts) recognized earlier by Wilson. This concept has been used for determining the directions and directional changes of plate motions in many parts of the world. EI.W. Menard (1973) demonstrated the relationship between age and depth of ocean crust, initiating a series of studies on use of this concept as an age criterion. The first of several maps showing the age of ocean floor rocks based on interpretation of the magnetic patterns was produced by Pitman, Larson and Herron in 1974.

In studying the Tonga-Kermadec and Marianas are systems, D. Karig (1971) observed a poorly understood phenomenon, later identified in other areas as well and now called "behind-the-are spreading." Compression and subduction on the trench side of an arc is apparently accompanied by rifting and extension of the older voleanic rocks of the inner arc. Crustal compression and extension obviously occur in close proximity; hence the lithosphere is not subjected to an all-pervasive compressive stress.

In recent years small submarines have allowed direct observation of outcropping ocean rocks. Among the unexpected findings were springs of warm to superheated water on the spreading ridges. Some of the springs yield enormous volumes of hot water and generate polymetallic sulphide deposits identical to known ore bodies on land. These springs indicate that convectively circulating hot seawater has leached metals and non-metallic elements from porous volcanic rock and concentrated them near active vents. The discovery reinforces current views of economic geologists that emphasize the role of groundwater in leaching, transporting and, ultimately, concentrating useful minerals.

In concert with continuing ocean exploration, it is evident that an energetic program of exploration of the continents is required. A principal objective is the application of the

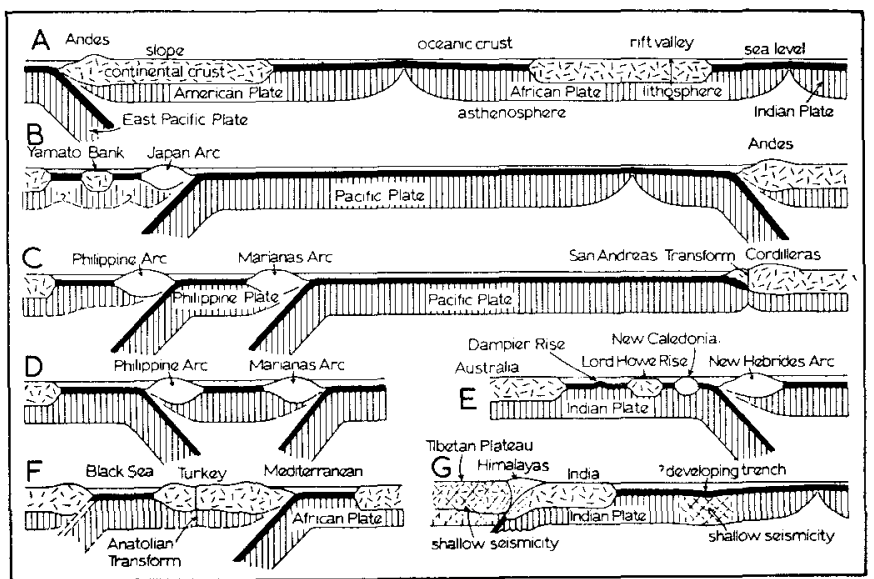

Figure 6: Mountain belts and plate tectonics. From Dewey and Bird, 1970. 
plate tectonics model to gaining a better understanding of the processes by which continents are assembled. The most important processes currently recognized involve accretion of island arcs and "suspect terranes" to continental margins, and continent-continent collision. Island arcs are characterized by andesitic volcanism and plutonism, and mélanges with associated ophiolitic masses and blueschist-type metamorphic rocks are present in most.

The mechanisms for mélange formation are now reasonably well understood (Raymond, 1984), ophiolites apparently originated as ocean crust and as a part of island arcs, but the source or sources of andesitic magmas are still debated. Blueschists form at high pressure and relatively low temperature, suggesting subduction to depths of $10 \mathrm{~km}$ or more, and a rapid return to shallow depths, thus preventing inversion to more stable minerals. ilark Cloos (1984) proposed that rapid upward transport of blueschists is brought about by the return flow of mélange during subduction (Fig. 7).

The Alps and Himalayas are classic examples of mountains now believed to have formed as a result of continentcontinent collision, creating larger continents. Only recently has it been determined that portions of the mountain ranges bordering eastern and western North America are composed of "suspect" terranes (Fig. 8), many of which were accreted to the pre-existing continent. Their composition and paleomagnetic and fossil evidence indicate that these terranes originated as parts of continents, island arcs or ocean crust, far from their present position (Coney, Jones and Monger, 1980; Williams and Hatcher, 1982). In view of the demonstrated importance of this phenomenon on the margins of North America (see also Crowell, and Stone and Wallace, this issue), it is likely that a significant amount of older continental crust, in North America and elsewhere, was assembled in this way.

\section{Exploration of Continental Crust}

The systematic exploration of North American continental crust is moving forward in two major programs: deep seismic-relection profiling and deep exploratory drilling. The Consortium for Continental Reflection Profiling (COCORP) began a program of deep seismic exploration in 1974 , undertaking a comprehensive reconnaissance of major crustal features by surveying grids of seismic reflection profiles (Brown et al., 1986). Over $6000 \mathrm{~km}$ of line have been completed, and important and unexpected features were found in every area examined (Fig. 9).

The southern Appalachian program, for example, detailed a complex accretion history marked by nearly horizontal thrust surfaces and a doubling of the crust. Equally striking

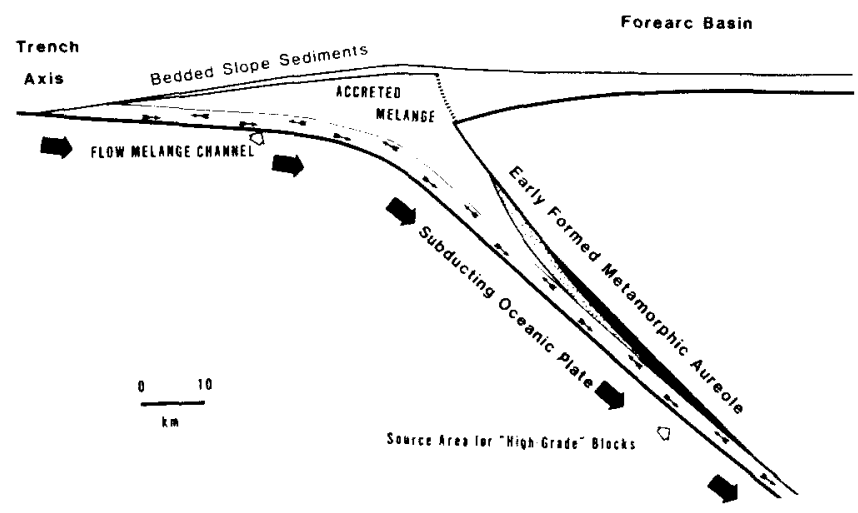

Figure 7: Formation of blueschist-grade rocks in a subduction zone, followed by erosion of hanging wall and upward transport of blueschist by return flow of mélange. From Cloos, 1984.

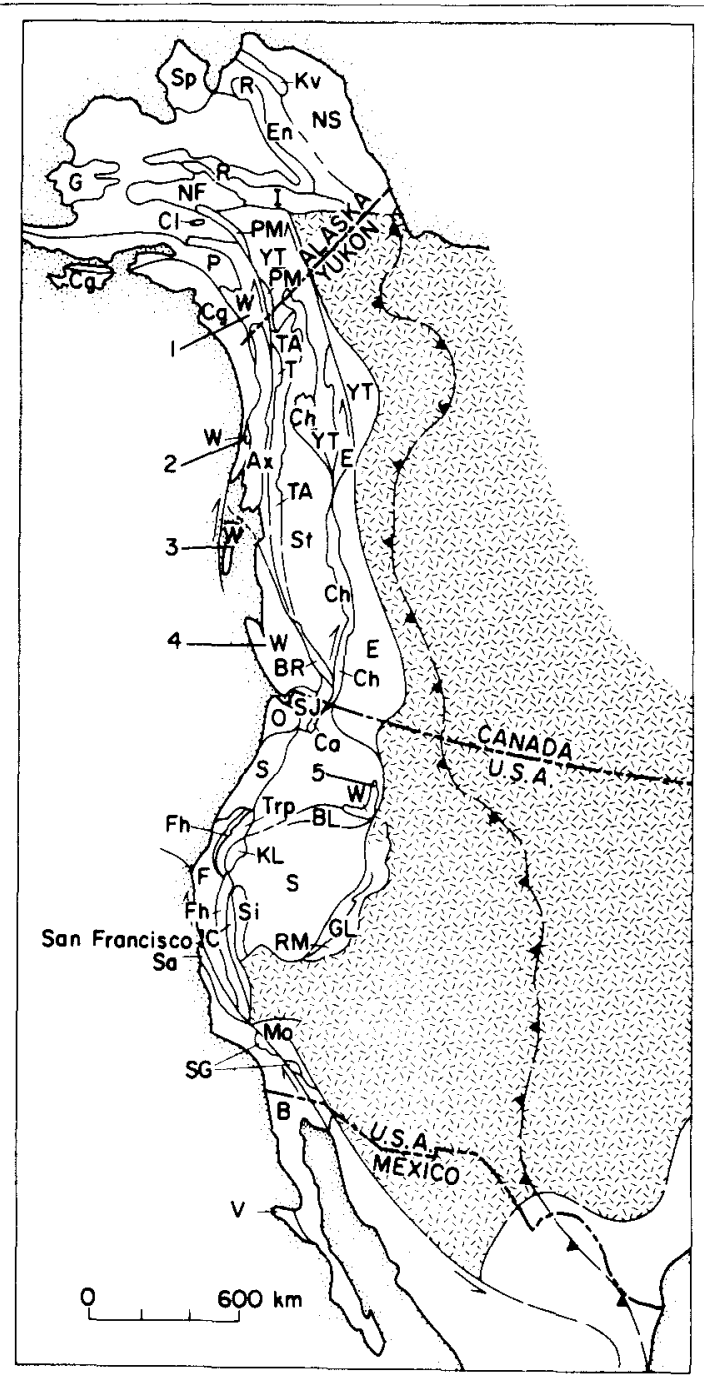

Figure 8: Suspect terranes, most of which were probably accreted to the western margin of the North American plate (stippled). From Coney, Jones and Monger, 1980.

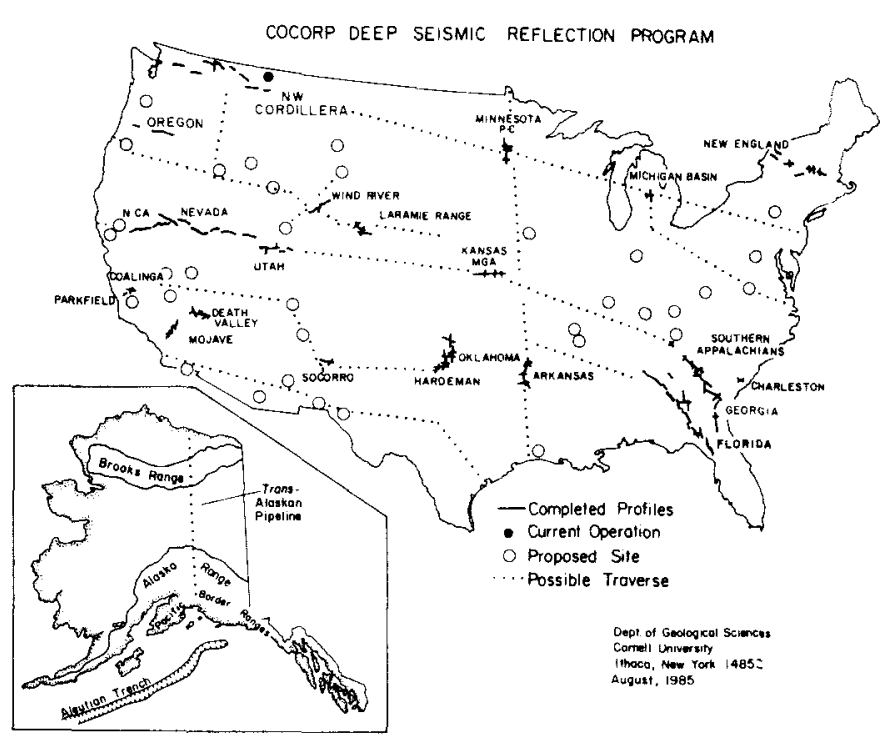

Figure 9: COCORP program for deep seismic profiles of the United States. From Brown et al, 1986. 
are seismic sections in the Basin and Range Province showing low-angle gravity faults cutting through most of the crust to accommodate extreme crustal stretching. Reflection seismic images of the Mohorovicic discontinuity are especially interesting. The base of the crust over much of the U.S.A. is marked by a zone, about $1 \mathrm{~km}$ thick, of nearly horizontal but discontinuous reflections. Presumably this layered zone was generated by an interaction of unknown nature between the crust and mantle.

The first deep hole in the U.S. program is now being drilled at Cajon Pass in southern California near the San Andreas fault. A major objective of this drill hole is to investigate the apparently nearly frictionless behavior of rocks in this part of the fault zone, as deduced from smaller than anticipated thermal gradients. Other sites are now being evaluated, including the Katmai fumarolic area in Alaska; an epithermal ore deposit at Creede, Colorado; a regional structure site in the southern Appalachians, and a site to explore deep petroleum-source beds and transitional crust in the Gulf Coast of Texas.

\section{Exploring the Earth's Interior}

With the advent of ultra high-speed computers and of global networks offering high-quality digital seismic data, a new process, seismic tomography, has opened exciting avenues for exploring the earth's interior. Data from earthquakes around the world have been analyzed to display velocity variations along ray paths penetrating the mantle and outer core (Dziewonski and Anderson, 1984; Dziewonski and
Woodhouse, 1987). The resulting, very generalized tomographic models depict broad linear regions of relatively low velocity in the upper mantle roughly corresponding to the great spreading ridges, and intervening areas of higher velocities beneath continents and old ocean basins. Similar zones of contrasting velocity are revealed in the lower mantle and the outer core. It is tempting to interpret this velocity distribution as an indication of the temperature variation to be expected in convecting systems within the mantle and outer core. This project, coupled with current seismic investigations of the lithosphere, has the potential to provide a realistic model of a dynamic earth, the beginning perhaps of yet another revolution in the earth sciences.

Dr. J.C. Maxwell is Emeritus Professor at the University of Texas (Austin, TX 78712). He has been President of the American Geological Institute, and of the Geological Society of America, Chairman of the U.S. National Committee for Geodynamics, and Vice-Chairman of the Board of IGCP. His research interests are in regional tectonics, particularly of the northwestern U.S.A. and Mediterranean areas.

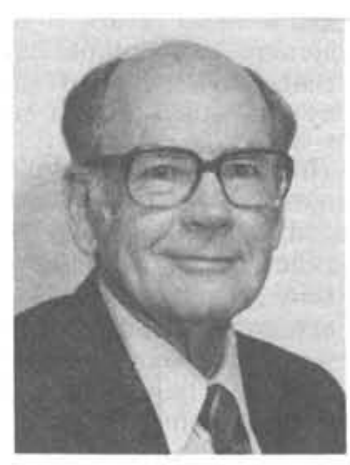

\section{References}

Atwater, T., 1970. Implications of plate tectonics for the Cenozoic tectonic evolution of western North America. Geological Society of America Bulletin, v. 81, no. 12, p. 3513-3536.

Benioff, H., 1955. Seismic evidence for crustal strueture and tectonic activity. In: Poldervaart, A. (ed.), Crust of the Earth. Geological Society of America Special Paper 62, p. 61-73.

Bowen, N.L., 1928. Evolution of the Igneous Rocks. Princeton University Press, Princeton, N.J., 332p.

Brown, L.D., Barazangi, M. Kaufman, S. and Oliver, J., 1986. The first decade of COCORP: 1974-1984. In: Reflection Seismology: A Global Perspective. American Geophysical Union Geodynamies Series, v. 13, p. 107-120.

Cloos, M., 1984, Flow mélanges and the structural evolution of accretionary wedges. In: Raymond, L.A. (ed.), Mélanges: their Nature, Origin, and Significance. Geological Society of America Special Paper 198, p. 71-79.

Coney, P.J., Jones, D.L. and Monger, J.W.H., 1980. Cordilleran suspect terranes. Nature, v. 288, no. 5789, p. 329-333.

Cox, A., Doell, R.R. and Dalrymple, G.B., 1963. Geomagnetic polarity epochs and Pleistocene geochronometry. Nature, v. 198 , no. 4885 , p. 1049-1051.

Dewey, J.F. and Bird, J.M., 1970. Mountain belts and The New Global Tectonics. Journal of Geophysical Research, v. 75, no. 14, p. 2625-2647.

Dietz, R.S., 1961. Continental and ocean basin evolution by spreading of the sea-floor. Nature, v. 190, no. 4779 , p. $854-857$.

Dziewonski, A.M. and Anderson, D.L., 1984. Seismic tomography of the earth's interior. American Scientist, v. 72, no. 5, p. 483-494.

Dziewonski, A.M. and Woodhouse, J.H., 1987. Global images of the earth's interior. Seience, v. 236, no. 4797 , p. $37-48$.

Griggs, D.T., 1939. A theory of mountain building. American Journal of Science, v. 237, no. 9, p. 611-650.

Hstherton, T. and Dickinson, W.R., 1969. The relationship between andesitic volcanism and seismicity in Indonesia, the Lesser Antilles and other island ares. Journal of Geophysical Research, v. 74 , no. 22 , p. 5301-5310.

Heezen, B.C. and Tharp, M., 1968. Physiographic diagram of the North Atlantic Ocean. Geological Society of America. Special Paper 65, (map and text), part 2 .

Heezen, B.C., Tharp, M. and Ewing, M., 1959. The Floors of the Oceans: I. The North Atlantic. Geological Society of America Special Paper 65, 122p. plus plates.

Heirtzler, J.R., Dickson, G.O., Herron, E.M., Pitman, W.C. and LePichon, X., 1968. Marine magnetic anomalies, geomagnetic field reversals, and motions of the ocean floor and continents. Journal of Geophysical Research, v. 73, no. 6, p. 2119-2136.

Hess, H.H., 1939. Island ares, gravity anomalies and serpentine intrusions: A contribution to the ophiolite problem. International Geological Congress, Report of the XVII Session, v. 2, p. 263-283.

Holmes, A., 1931. Radioactivity and earth movements. Geological Society of Glasgow Transactions (for 1928-29), v. 18, pt. 3, p. 559-606.

Isacks, B., Oliver, J. and Sykes, L.R., 1968. Seismology and the new global tectonics. Journal of Geophysical Research, v. 73 , no. 18 , p. $5855-5899$.

Karig, D.E., 1971. Structural history of the Mariana Island are system. Geological Society of America Bulletin, v. 82 , no. 2, p. 323-344.

Kay, G.M., 1951. North American geosynclines. Geological Society of America Memoir 48, 143p.

King, P.B., 1959. The Evolution of North America. Princeton University Press, Princeton, N.J., 190p.

Kuenen, P.H., 1934. Relations between submarine topography and gravity fields. In: Vening Meinesz, F.A., 1934, Gravity Expeditions at Sea, 1923-1932, v. 2 , p. $183-194$.

Hess, H.H., 1962. History of ocean basins. In: Engel, A.E., James, H.L. and Leonard, B.F. (eds.). Petrologic Studies: A volume to Honor A.F. Buddington. Geological Society of America, Boulder, Colo., p. 599-620.
Mason, R.G. and Raff, A.D., 1961. Magnetic survey of the west coast of North America, $32^{\circ} \mathrm{N}$. latitude to $42^{\circ} \mathrm{N}$. latitude. Geological Society of America Bulletin, v. 72, no. 8, p. 1259-1266.

Maxwell, A. and others, 1970, Deep sea drilling in the south Atlantic. Seience, v. 168, p. 1047-1059.

Menard, H.W., 1973, Epeirogeny and plate tectonics. EOS, American Geophysical Union Transactions, v. 54, no. 12, p. 1244-1256.

Morgan, W.J., 1968. Rises, trenches, great faults, and crustal blocks. Journal of Geophysical Research, v. 73 , no. 6 , p. 1959-1982.

Morgan, W.J., 1971. Convection plumes in the lower mantle. Nature, v. 230 , no. 5288 , p. $42-43$.

Pitman, W.C., Larson, R.L. and Herron, E.M., 1974. The age of the ocean basins. Geological Society of America Map and Chart Seríes, M C-6.

Raymond, L.A. (ed.), 1984. Mélanges: their Nature, Origin, and Significance. Geological Society of America Special Paper 198, 170p.

Schuchert, C., 1931. Outlines of Historical Geology, 2 and ed., rewritten John Wiley and Sons, New York, $348 \mathrm{p}$.

Sykes, L.R., 1967. Mechanism of earthquakes and nature of faulting on the mid-ocean ridges. Journal of Geophysical Research, v. 72, no. 8, p. 21 31-21 53.

Taylor, F.B., 1910. Bearing of the Tertiary mountain belt on the origin of the Earth's plan. Geological Society of America Bulletin, v. 21, p. 179-226.

Vening Meinesz, F.A., 1934. Gravity Expeditions at Sea, 1923-1932, v. 2, 208 p.

Vine, F.J. and Matthews, D.H., 1963. Magnetic anomalies over oceanic ridges. Nature, v. 199, no. 4897 , p. $947-949$.

Williams, H. and Hatcher, R.D., Jr., 1982. Suspect terranes and accretionary history of the Appalachian orogen. Geology, v. 10, no. 10, p. 530-536.

Wilson, J.T., 1963. A possible origin of the Hawaiian Islands. Canadian Journal of Physies, v. 41 , no. 6, p. 863-870.

Wilson, J.T., 1965. A new class of faults and their bearing on continental drift. Nature, v. 207, no. 4995 , p. $343-347$. 